\title{
Nuclear transfer of putative rabbit embryonic stem cells leads to normal blastocyst development
}

\author{
F. Du ${ }^{1}$, J. R. Giles ${ }^{1}$, R. H. Foote ${ }^{1}$, K. H. Graves ${ }^{2}$, X. Yang ${ }^{1}$ and \\ R. W. Moreadith ${ }^{2 *}$ \\ ${ }^{1}$ Department of Animal Science, Cornell University, Ithaca, New York, USA; and ${ }^{2}$ The Molecular \\ Cardiology Laboratories, The University of Texas Southwestern Medical Center, Dallas, TX 75235-8573, \\ USA
}

\begin{abstract}
Rabbit embryonic stem-like cells, characterized by embryoid body formation and differentiation into cell types representative of all three germ layers, were studied for their ability to promote early embryonic development after nuclear transfer. After culture of the reconstructed embryos, $23 \%(n=35)$ developed successfully into morulae or blastocysts, compared with $34 \%(n=62)$ for cloned embryos derived from nuclear transfer with embryonic blastomeres. The cloned embryos from the embryonic stem-like cells appeared normal, with an average of $26 \%$ inner cell mass cells, similar to that of control non-manipulated embryos (25\%) or cloned embryos from blastomeres $(25 \%)$. Thus, nuclear transfer of rabbit embryonic stem-like cells leads to early embryonic development that is indistinguishable from blastomere fusion. These results have implications for the development of gene targeting in a species (rabbit) that may be a more suitable model for studying certain human diseases. In addition, this technique may be applicable to other species from which putative embryonic stem cells have been derived, particularly agriculturally important animals.
\end{abstract}

\section{Introduction}

Pluripotent embryonic stem (ES) cells or ES-like cells have been derived from preimplantation embryos of several mammals, including mice (Evans and Kaufman, 1981; Martin, 1981), hamsters (Doetschman et al., 1988), pigs (Notarianni et al., 1990), cattle (Saito et al., 1992; Strelchenko and Stice, 1994), mink (Sukoyan et al., 1992), rats (Iannaccone et al., 1994) and rabbits (Graves and Moreadith, 1993). In several instances, these have been passaged continuously in culture without loss of the undifferentiated phenotype, and display many of the characteristics expected of pluripotential cells. In culture, the cells can be induced to differentiate terminally into cell types representing each of the germ layers after embryoid body formation (pluripotentiality). However, only in mice has germline pluripotency, the ability of the ES cells alone to give rise to viable germline animals, been demonstrated (Nagy et al., 1993). This property and the ability to introduce precise mutations in these cells in tissue culture via homologous recombination are important advances in mouse developmental genetics. It is now theoretically possible to produce mice of almost any genotype, and to investigate the consequences of defined mutations in the context of an intact animal. The technology promises to address diverse issues important in mammalian developmental biology and medicine.

*Correspondence.

Received 6 January 1995.
The current methods for production of germline chimaeras use either injection of the putative ES cells directly into a blastocyst, co-culture with zona-free morulae to produce aggregation chimaeras (Wood et al., 1993), or injection of the cells into tetraploid embryos generated by cell fusion (Nagy et al., 1993). These procedures have been successful only in mice.

Nuclear transfer represents an additional technique for the production of viable offspring from ES-like cells (Sims and First, 1994). With this method, early cleavage stage embryonic cells (typically blastomeres, but also inner cell mass cells) are individually isolated and fused with enucleated mature oocytes (for recent review see Robl et al., 1992). Nuclear transfer with blastomeres has resulted in progeny in several species, including sheep (Willadsen, 1986, 1989), cattle (Prather et al., 1987; Bondioli et al., 1990), pigs (Prather et al., 1989) and rabbits (Stice and Robl, 1988; Yang et al, 1992). In cattle, numerous offspring have been produced through serial nuclear transfer using embryonic cells at 8-32-cell stages (Stice and Keefer, 1993). However, in mice, nuclear transfer with blastomeres beyond the two-cell stage has been unsuccessful (McGrath and Solter, 1983, 1984). In addition, attempts to use mouse ES cells for nuclear transfer result in implantations but no viable progeny (Tsunoda and Kato, 1993). This finding suggests that mouse ES cell lines represent true inner cell mass (ICM) cells, and that they cannot contribute to normal extraembryonic development (or that the techniques used are insufficient for complete embryonic development). Unfortunately, except for 
mouse ES cells, there have been no continuously passaged mammalian ES cell lines that have been shown to contribute to normal development by production of germline chimaeras after blastocyst injection or nuclear transfer. However, the encouraging results with nuclear transfer of blastomeres and briefly cultured ICM cells in species other than the mouse (Keefer et al., 1994; Sims and First, 1994; Stice et al., 1994) opens up the possibility of producing viable animals through nuclear transfer of ES cells that retain totipotential properties.

Graves and Moreadith (1993) reported the derivation of several putative ES cell lines in rabbits. The current report describes the results of attempts to demonstrate that these ES-like cells can contribute to normal development. In this study, nuclear transfer, using two separate, serially passaged rabbit cell lines into enucleated rabbit oocytes led to normal blastocyst development. This finding has important implications for the subsequent development of rabbit models of disease, and may be broadly applicable to undifferentiated cells in other species.

\section{Materials and Methods}

\section{Cell culture reagents}

Murine leukaemia inhibitory factor (LIF) and Dulbecco's minimal essential medium (DMEM) were obtained from Gibco Life Technologies (Grand Island, NY); fetal bovine serum (FBS) was obtained from Hyclone (Logan, UT).

\section{Animals}

Sexually mature albino Dutch rabbits maintained at Cornell University under a $12 \mathrm{~h}$ light: $12 \mathrm{~h}$ dark cycle were superovulated using a modified procedure of Kennelly and Foote (1965) with FSH (FSH-P; Schering Corp., Kenilworth, NJ) and LH (Vetrepharm Inc., London, Canada). Embryo donor females were artificially inseminated at the time of $\mathrm{LH}$ injection with semen collected from fertile males. Oocytes and embryos were collected by midventral laparotomy and flushing the oviducts with Dulbecco's PBS (GIBCO, Grand Island, NY) plus $0.3 \%$ (w/v) BSA (Fraction V; Sigma St Louis, MO).

\section{Cell culture and nuclear transfer}

The derivation and culture conditions of rabbit ES-like cells was described by Graves and Moreadith (1993). Two of the most carefully characterized cell lines, GM3 and GMII (at passage 7), were thawed, washed once in DMEM, and resuspended in PBS plus $15 \%(\mathrm{v} / \mathrm{v})$ FBS containing $7.5 \mu \mathrm{g}$ cytochalasin B ml ${ }^{-1}$ (Sigma). Oocytes were collected 14-15 h after $\mathrm{LH}$ injection from donor females; the oocytes were freed of cumulus cells by vortexing in $0.2 \%(\mathrm{w} / \mathrm{v})$ hyaluronidase in PBS plus $0.1 \%(\mathrm{v} / \mathrm{v})$ polyvinyl alcohol (PVA; Sigma), washed and held in PBS plus $15 \%(\mathrm{v} / \mathrm{v})$ FBS containing $7.5 \mu \mathrm{g}$ cytochalasin $\mathrm{B} \mathrm{ml}^{-1}$ for $20 \mathrm{~min}$ before enucleation. Enucleation of oocytes was performed as described by Yang et al. (1992).

Donor cells were either blastomeres from cleavage stage rabbit embryos or the rabbit ES-like cells. For blastomere donor cells, embryos at the 16-cell stage were collected from super- ovulated, naturally mated does $48-50 \mathrm{~h}$ after injection of $\mathrm{LH}$ and artificial insemination. The mucin coat and the zona pellucida were removed essentially as described by Yang et al. (1990). Embryos were treated with acidic PBS ( $\mathrm{pH} \mathrm{2.4)}$ for 1-2 min at room temperature and transferred to $0.5 \%(\mathrm{w} / \mathrm{v})$ pronase $\mathrm{E}$ (Sigma) in PBS for $\mathrm{I}-2 \mathrm{~min}$ at $39^{\circ} \mathrm{C}$ until the mucin coat and zona were removed. The mucin/zona-free embryos were then washed in PBS plus $15 \%(v / v)$ FBS, incubated in $0.25 \%(w / v)$ trypsin in Hank's buffered salt solution for 1-2 min and gently pipetted with a polished pipette to disaggregate the blastomeres. Blastomeres were washed in PBS plus $15 \%(v / v)$ FBS and transferred to a microdrop of PBS plus $10 \%(\mathrm{v} / \mathrm{v})$ FBS containing $7.5 \mu \mathrm{g}$ cytochalasin $\mathrm{B} \mathrm{ml}{ }^{-1}$. A blastomere or a small round refractile ES-like cell was transferred to the perivitelline space of an enucleated oocyte. Care was taken to place the small ES-like cell in close contact with the vitelline membrane of the oocyte.

Enucleated oocytes with or without transferred donor cells were transferred to the activation chamber containing activation medium $\left(0.3 \mathrm{~mol}\right.$ D-mannitol $\mathrm{l}^{-1}, 0.05 \mathrm{mmol}$ calcium chloride $\mathrm{I}^{-1}$ and $0.1 \mathrm{mmol}$ magnesium sulfate $\mathrm{l}^{-1}$ ), aligned with an $A C$ pulse of $0.1 \mathrm{kVcm}^{-1}$ for 5-10 $\mathrm{s}$ and pulsed with $2.4 \mathrm{kV} \mathrm{cm}^{-1} \mathrm{DC}$ for $60 \mu \mathrm{s}$ (Yang et al., 1992). About $30 \mathrm{~min}$ later, the oocyte-cell complexes were transferred to activation medium and pulsed again as described above. After washing, they were incubated for a further $30 \mathrm{~min}$ in cytochalasin $B$, washed in culture medium and cultured in microdrops as described below.

The manipulated oocytes or embryos were cultured in $50 \mu \mathrm{l}$ droplets of modified RD medium (Carney and Foote, 1991) overlaid with medical fluid (Dow Corning) at $39^{\circ} \mathrm{C}$ under a humid atmosphere of $10 \% \quad \mathrm{CO}_{2}: 5 \% \quad \mathrm{O}_{2}: 85 \% \quad \mathrm{~N}_{2}$. The RD medium consisted of a I:I mixture of DMEM (low glucose) and RPMI-1640 (Gibco), modified from the earlier 1:I mixture of high glucose DMEM and RPMI-1640 described by Li et al. (1993). In modified RD medium, DMEM (low glucose) plus $0.1 \%(w / v)$ PVA was used. Nuclear transfer embryos, as well as enucleated oocytes, were cultured for 5 days. In addition, a subset of non-manipulated donor embryos were cultured for 2-3 days as controls.

After culture, the mucin coat and the zona pellucida were removed from embryos as described above. Embryos were either fixed in sodium citrate:ethanol and stored at $5^{\circ} \mathrm{C}$ until examination or they were subjected to complement-mediated cell lysis (immunosurgery) as described by Solter and Knowles (1975) and Giles et al. (1993) and then fixed. After fixation, embryos were transferred to a $100 \mu \mathrm{l}$ droplet of sodium citrate:ethanol containing $10 \mu \mathrm{g}$ Hoechst $33342 \mathrm{ml}^{-1}$ and $10 \mu \mathrm{g}$ propidium iodide $\mathrm{ml}^{-1}$ (Sigma) and incubated at room temperature for 3-4 min. For blastocysts subjected to the immunosurgery procedure, the nuclei of the ICM and trophectoderm cells were differentially stained and fluoresced blue and pink, respectively, under a fluorescent microscope (Handyside and Hunter, 1984). Cell nuclei of embryos that were not allocated to the immunosurgery procedure were labelled with Hoechst 33342. They were then transferred to a $2-3 \mu \mathrm{l}$ droplet of PBS:glycerol ( $1: 1)$ on a glass slide, examined as whole mount, then gently squashed by a coverslip and counted. Photomicrographs were taken of selected embryos following fixation and staining. 
Table 1. Nuclear transplantation of rabbit blastomeres and embryonic stem (ES)-like cells

\begin{tabular}{lccccr}
\hline $\begin{array}{l}\text { Donor cell } \\
\text { types }\end{array}$ & $\begin{array}{c}\text { Number of } \\
\text { enucleated oocytes }\end{array}$ & $\begin{array}{c}\text { Number (\%) } \\
\text { fused }\end{array}$ & Pre-morula & Morula & Blastocyst \\
\cline { 5 - 6 } None $^{\mathrm{a}}$ & 15 & 0 & 0 & 0 & 0 \\
Blastomere $^{\mathrm{b}}$ & 69 & $62(90)$ & $9(15)$ & $2(3)$ & $19(31)$ \\
GM 3 & 28 & $17(61)$ & $4(7)$ & $2(12)$ & $5(29)$ \\
GM 11 & 30 & $18(60)$ & $4(22)$ & 0 & 1 \\
\hline
\end{tabular}

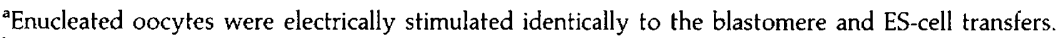

${ }^{b}$ Combined results of two experiments.

'ES-like cells were from passage 7 .

Table 2. Total cells and inner cell mass (ICM) cells in rabbit blastocysts derived from nuclear transfer with embryonic stem (ES)-like cells

\begin{tabular}{|c|c|c|c|c|}
\hline \multirow[b]{2}{*}{ Experiment } & \multirow{2}{*}{$\begin{array}{l}\text { Number of } \\
\text { blastocysts }\end{array}$} & \multicolumn{3}{|c|}{ Number of nuclei } \\
\hline & & Total & ICM & $\%$ ICM \\
\hline A Control fertilized embryos ${ }^{a}$ & 16 & 255 & 63 & 25 \\
\hline Blastomere fused ${ }^{b c}$ & 9 & 126 & 32 & 25 \\
\hline GM 3 cell fused $^{\text {bd }}$ & 4 & 132 & 35 & 27 \\
\hline B Control fertilized embryos ${ }^{a}$ & 14 & 212 & 56 & 26 \\
\hline Blastomere fused ${ }^{\mathrm{b}}$ & 7 & 97 & - & - \\
\hline GM II cell fused ${ }^{b}$ & 1 & 85 & - & - \\
\hline
\end{tabular}

${ }^{a}$ Embryos were recovered 2 days after LH/AI and cultured for 2 days.

${ }^{b}$ Nuclear transfer embryos were cultured for 5 days.

'Three small blastocysts were not included (total cells $=34$; ICM $=5$ ).

'One small blastocyst had 34 nuclei (all fluorescing pink) and was not included.

\section{Results}

\section{Nuclear transfer with ES-like cells and blastomeres}

Table 1 lists the combined results of the nuclear transfer experiments using blastomeres and ES-like cells. Embryos at the sixteen-cell stage $(n=31)$ were collected from two superovulated donor females to serve as blastomere donors. These embryos were of high quality by morphological criteria, and two (from the same donor) were used for nuclear transfers. Two of the most completely characterized ES-like cell lines (GM3 and GM11) were thawed and used directly (without brief culture) for nuclear transfer with the same batches of enucleated oocytes. The numbers of manipulated oocytes developing into either morulae or blastocysts are shown for each series of manipulations. As expected, enucleated oocytes did not overlap further and, in most instances, degenerated after a few divisions. However, the control oocytes injected with blastomeres showed normal blastocyst development by morphologic criteria in 19 of 62 fused enucleated oocytes $(31 \%)$. In addition, both GM3 and GM11 ES-like cell lines supported blastocyst formation after nuclear transfer with development into blastocysts (5 of 17, 29\%) similar to the blastomere controls $(31 \%)$.

\section{Cell lineage analysis of cloned embryos}

When blastocysts from each experimental group were examined under the microscope for development of presumptive ICM and trophectoderm cells, the ICM ratios of enucleated oocytes receiving blastomeres were the same as those of ES-like cells or non-manipulated control embryos $(27 \%, 25 \%$ and $25 \%$, respectively; Table 2 and Fig. 1). These results demonstrate that nuclear transfer of putative rabbit ES cells results in blastocyst development that is indistinguishable from blastomere transfer or normal embryonic development in unmanipulated controls.

\section{Discussion}

The technique of gene targeting in ES cells has resulted in the production of several hundred novel genotypes in mice. However, the technique has been successful only in mice. While they may prove to be the preferred animals for some questions pertaining to developmental biology in mammals, mice are too small to be easily manipulated for a variety of studies where extensive surgery or invasive manipulation is required. Larger mammals, such as rabbits, would provide investigators with the potential to produce animal models that 

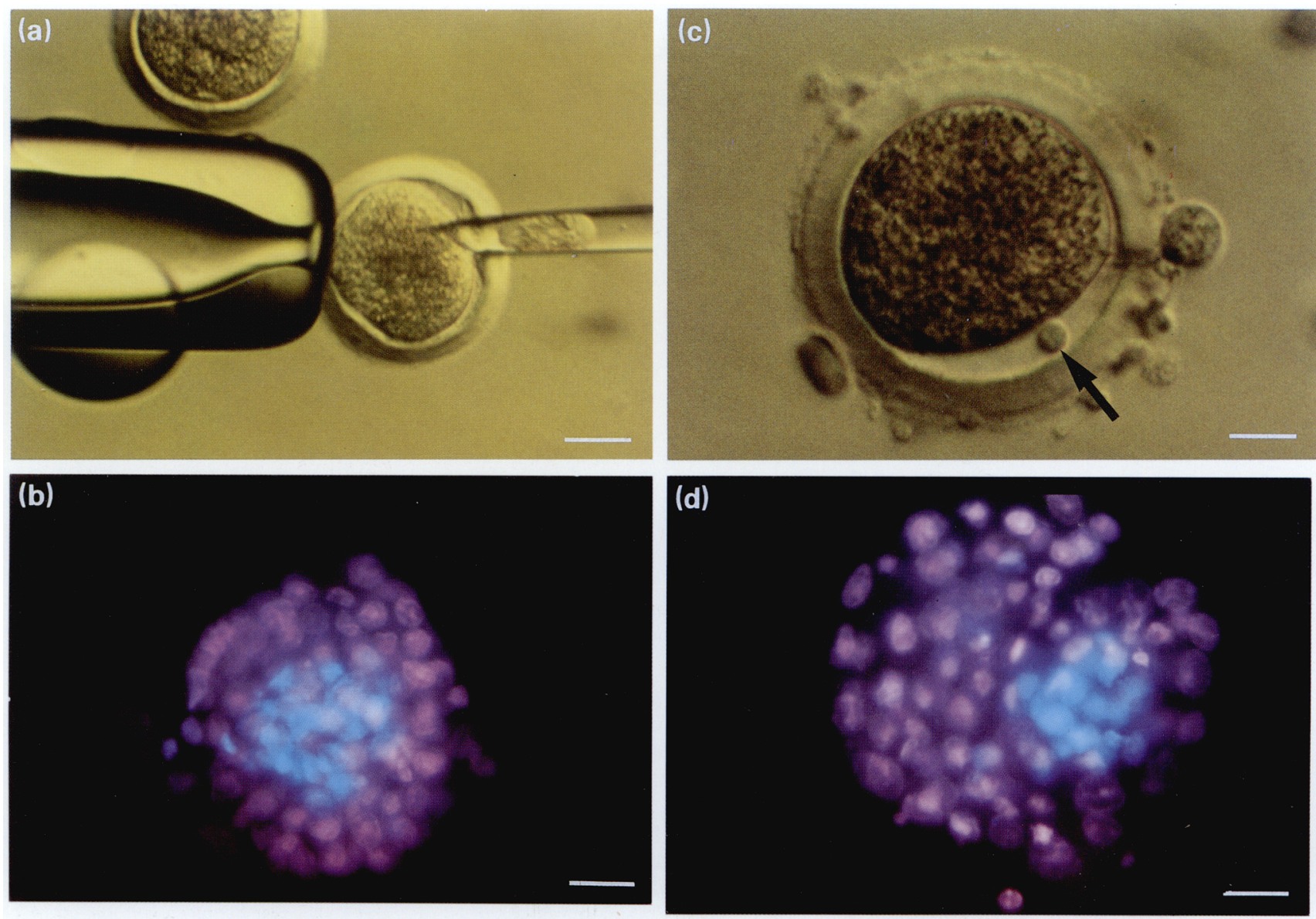

Fig. 1. Nuclear transplantation of rabbit blastomeres and embryonic stem (ES)-like cells. (a) An enucleated oocyte with injection of a blastomere at the 16-cell stage. (b) Dual staining of a blastocyst derived from nuclear transfer of a single blastomere. (c) An enucleated oocyte with a rabbit ES-like cell (arrow). (d) Dual staining following nuclear transfer and blastocyst development with a rabbit ES cell. Scale bars represent $40 \mu \mathrm{m}$ in (a) and $20 \mu \mathrm{m}$ in (b), (c) and (d)

might be more easily studied and reflect human disease more accurately.

The long-term goal of this work is to develop gene targeting technology in rabbits. Graves and Moreadith (1993) reported the characterization of pluripotential ES-like cells from rabbits. The present study furthers the investigation of these cells by nuclear transfer approaches. After nuclear transfer, these cells appeared to promote normal development, at least up to the blastocyst stage. The development is indistinguishable from embryo development after nuclear transfer with blastomeres as donor cells, and this suggests that these cells may retain the ability to differentiate into normal embryos. These results are consistent with similar studies in cattle nuclear transfer with ES-like cells (Stice et al., 1994; Strelchenko and Stice, 1994). Sims and First (1994) reported the birth of normal calves following nuclear transfer of briefly cultured (for up to 28 days) ICM cells in suspension, demonstrating that immunosurgically isolated ICM cells retain totipotential characteristics. Inner cell mass cells carried in culture for longer than 28 days did not result in offspring, and attempts to establish them in culture by standard techniques failed to give rise to cell lines.

Embryo transfer of the cloned embryos with ES-like cells was not conducted in this study, but work is in progress to do so. However, cell lineage analysis for development of ICM and trophectoderm cells in the resulting blastocysts demonstrated similar ICM:trophectoderm ratios in the ES-like cells compared with blastomere cloned embryos and non-manipulated controls. Since ICM cells, but not trophectoderm cells, can support blastocyst development (Collas and Robl, 1991), these results suggest that these ES-like cell lines may support not only embryonic development but extraembryonic tissue development as well. Despite these encouraging results, it is worth noting that blastocyst development resulting from nuclear transfer may not reflect true totipotency of these cells, since blastocysts derived from multiple serial nuclear transfer or nuclear transfer with cumulus cells have failed to establish pregnancy in cattle (Stice and Keefer, 1993; Collas and Barnes, 1994). Additional studies will ascertain whether these nuclear transfer blastocysts will give rise to normal, fertile rabbits when transferred into recipients.

The implications of this work, and work in other species, suggest that it may be possible to derive pluripotential, and perhaps totipotential, ES cell lines that can be serially passaged and still give rise to normal embryonic development. Additional studies will address the conditions under which the parental cells contribute to the production of normal animals. 
Eventually, advancement of gene targeting techniques may allow the production of rabbits with mutations implicated in human disease. These animals would be of great utility in the development of novel approaches to therapy in humans, particularly gene therapy. In addition, these studies may be extended to potential applications in animals of commercial importance.

This study was supported by grants from the American Heart Association, Texas Higher Education Coordinating Board Advanced Technology Program and NIH (RO1-HL-51568) to R. W. Moreadith; the Cornell Biotechnology Program, supported by the New York State Science and Technology Foundation and a Consortium of Industries and the National Science Foundation to X. Yang and a private grant by R. H. Foote. R. W. Moreadith is an Established Investigator of the American Heart Association. The technical expertise of W. F. Young and G. Albright is greatly appreciated.

\section{References}

Bondioli KR, Westhusin ME and Looney CR (1990) Production of identical bovine offspring by nuclear transfer Theriogenology 33 165-174

Carney EW and Foote RH (1991) Improved development of rabbit one-cell embryos to the hatching blastocyst stage by culture in a defined protein-free culture medium Journal of Reproduction and Fertility 91 113-123

Collas P and Barnes FL (1994) Nuclear transplantation by microinjection of inner cell mass and granulosa cell nuclei Molecular Reproduction and Development 38 264-267

Collas P and Robl JM (1991) Development of rabbit nuclear transplant embryos from morula and blastocyst stage donor nuclei Theriogenology 85190 (Abstract)

Doetschman T, Williams P and Maeda N (1988) Establishment of hamster blastocyst-derived embryonic stem (ES) cells Developmental Biology 127 224-227

Evans MJ and Kaufman MH (1981) Establishment in culture of pluripotential cells from mouse embryos Nature 292 154-156

Giles JR, Yang X, Mark W, Foote RH (1993) Pluripotency of cultured rabbit inner cell mass cells detected by isozyme analysis and eye pigmentation of fetuses following injection into blastocysts or morulae Molecular Reproduction and Development 36 130-138

Graves KH and Moreadith RW (1993) Derivation and characterization of putative pluripotential ES cell lines from preimplantation rabbit embryos Molecular Reproduction and Development 36 424-433

Handyside AH and Hunter S (1984) A rapid procedure for visualising the inner cell mass and trophectoderm nuclei of mouse blastocysts in situ using polynucleotide-specific fluorochromes Journal of Experimental Zoology 231 429-434

Iannaccone PM, Taborn GU, Garton, RL, Caplice MD and Brenin DR (1994) Pluripotent embryonic stem cells from the rat are capable of producing chimeras Developmental Biology 163 288-292

Keefer CL, Stice SL and Matthews DL (1994) Bovine inner cell mass cells as donor nuclei in the production of nuclear transfer embryos and calves Biology of Reproduction 50 935-939

Kennelly JJ and Foote RH (1965) Superovulatory response of pre- and post-pubertal rabbits to commercially available gonadotrophins Journal of Reproduction and Fertility 9 177-188

Li J, Foote RH and Simkin M (1993) Development of rabbit zygotes cultured in protein-free medium with catalase, taurine, or superoxide dismutase Biology of Reproduction 47 33-37
McGrath J and Solter D (1983) Nuclear transplantation in the mouse embryo by microsurgery and cell fusion Science 220 1300-1302

McGrath J and Solter D (1984) Inability of mouse blastomere nuclei transferred to enucleated zygotes to support development in vitro Science $\mathbf{2 2 6}$ 1317-1319

Martin GR (1981) Isolation of a pluripotential cell line from early mouse embryos cultured in medium conditioned with teratocarcinoma cells Proceedings of the National Academy of Sciences USA 78 7634-7638

Nagy A, Rossant J, Nagy R, Abramow-Newerly W and Roder JC (1993) Derivation of completely cell culture-derived mice from early-passage embryonic stem cells Proceedings of the National Academy of Sciences USA 90 8424-8428

Notarianni E, Laurie S, Moor RM, Evans MJ (1990) Maintenance and differentiation in culture of pluripotential embryonic cell lines from pig blastocysts Journal of Reproduction and Fertility Supplement 41 51-56

Prather RS, Barnes FL, Sims MM, Robl JM, Eyestone WH and First NL (1987) Nuclear transplantation in the bovine embryo assessment of donor nuclei and recipient oocyte Biology of Reproduction 37 859-866

Prather RS, Sims MM and First NL. (1989) Nuclear transplantation in early pig embryos Biology of Reproduction 41 414-418

Robl JM, Collas P, Fissore R and Dobrinsky J (1992) Electrically induced fusion and activation in nuclear transplant embryos. In Guide to Electroporation and Electrofusion pp 535-551 Eds DC Chang, BM Chasey, JA Saunders and AE Sowers. Academic Press, New York

Saito S, Strelchenko N and Niemann H (1992) Bovine embryonic stem cell-like cell lines cultured over several passages Roux's Archives Developmental Biology 201 134-141

Sims MW and First NL (1994) Production of calves by transfer of nuclei from cultured inner cell mass cells Proceedings of the National Acaderny of Sciences USA 90 6143-6147

Solter D and Knowles BB (1975) Immunosurgery of the mouse blastocyst Proceedings of the National Academy of Sciences USA 72 5099-5102

Stice SL and Keefer CL (1993) Multiple generational bovine embryo cloning Biology of Reproduction 48 715-719

Stice SL and Robl JM (1988) Nuclear reprogramming in nuclear transplant rabbit embryos Biology of Reproduction 39657-664

Stice SL, Strelchenko N, Belthauser J, Scott B, Jurgella G, Jackson J, David V, Keefer C and Matthews L (1994) Bovine pluripotent embryonic cells contribute to nuclear transfer and chimeric fetuses Theriogenology 41301

Strelchenko N and Stice S (1994) Bovine pluripotent cell lines derived from morula stage embryos Theriogenology 41304

Sukoyan MA, Golubitsa AN, Zhelezova AI, Shilov AG, Vatolin SY, Maximovsky LP, Andreeva LE, McWhir J, Pack SD, Bayborodin SI, Kerkis AY, Kizilova HI and Serov OL (1992) Isolation and cultivation of blastocyst-derived stem cell lines from American mink (Mustela vison) Molecular Reproduction and Development 33 418-431

Tsunoda Y and Kato Y (1993) Nuclear transplantation of embryonic stem cells in mice Journal of Reproduction and Fertility 98 537-540

Willadsen SM (1986) Nuclear transplantation in sheep embryos Nature 320 63-65

Willadsen SM (1989) Cloning of cow and sheep embryos Genome 31 956-962

Wood SA, Pascoe WS, Schmidt C, Kemler R, Evans MJ and Allen ND (1993) Simple and efficient production of embryonic stem cell embryo chimeras by co-culture Proceedings of the National Academy of Sciences USA 90 4582-4585

Yang X, Zhang L, Kovacs A, Tobback C and Foote RH (1990) Potential of hypertonic medium treatment for embryo micromanipulation: II. Assessment of nuclear transplantation methodology, isolation, subzona insertion and electrofusion of blastomeres Molecular Reproduction and Development 27 $118-129$

Yang X, Jiang S, Kovacs A and Foote RH (1992) Nuclear totipotency of cultured rabbit morulae to support full term development following nuclear transfer Biology of Reproduction $\mathbf{4 7}$ 636-643 